\title{
Secondary metabolites isolated from Richardia brasiliensis Gomes (Rubiaceae)
}

\author{
Danielle S. Pinto, ${ }^{*}, 1$ Anna Cláudia de A. Tomaz, ${ }^{1}$ Josean F. Tavares, ${ }^{1}$ Fábio H. Tenório- \\ Souza, ${ }^{1}$ Celidarque da Silva Dias, ${ }^{1}$ Raimundo Braz-Filho, ${ }^{2}$ Emídio V. L. da-Cunha ${ }^{*, 1,3}$
}

\author{
${ }^{1}$ Universidade Federal da Paraiba, Laboratório de Tecnologia Farmacêutica "Prof. Delby Fernandes de \\ Medeiros", 58051-970, João Pessoa-PB, Brazil, \\ ${ }^{2}$ Setor de Química de Produtos Naturais, Universidade Estadual Norte Fluminense, 28015-620 Campos-RJ, \\ Brazil, \\ ${ }^{3}$ Departamento de Farmácia e Biologia, Universidade Estadual da Paraíba, 58100-000 \\ Campina Grande-PB, Brazil
}

\begin{abstract}
RESUMO: "Metabólitos secundários isolados de Richardia brasiliensis Gomes (Rubiaceae)". A família Rubiaceae compreende cerca de 637 gêneros e aproximadamente 10700 espécies, ocorrendo essencialmente nas regiões tropicais do Brasil. Richardia brasiliensis Gomes, popularmente conhecida por "poaia branca", é uma planta nativa da região sul do Brasil, utilizada na medicina popular como anti-emética e no tratamento de diabetes. Este trabalho reporta o isolamento e identificação estrutural de um flavonóide glicosilado, um triterpeno, uma cumarina e dois derivados de ácido benzóico, objetivando contribuir para quimiotaxonomia do gênero Richardia. Através deste estudo foi possível isolar e identificar os metabólitos isorametina-3- $O$-rutinosídeo, ácido oleanólico, a cumarina escopoletina e os ácidos $p$-hidroxibenzóico e $m$-metoxi-p-hidroxi-benzóico, todos isolados pela primeira vez no gênero, exceto o último, apresentando, portanto, relevante importância quimiotaxonômica para o mesmo. As estruturas foram identificadas com o uso de técnicas espectroscópicas de IV, RMN ${ }^{1} \mathrm{H} \mathrm{e}{ }^{13} \mathrm{C}$ uni e bidimensionais e comparação com dados da literatura.
\end{abstract}

Unitermos: Rubiaceae, Richardia brasiliensis, isorametina-3-O-rutinosídeo, ácido oleanólico, escopoletina.

\begin{abstract}
The family Rubiaceae comprises around 637 genera and approximately 10,700 species, occurring essentially in tropical regions of Brazil. Richardia brasiliensis Gomes, known popularly as "poaia branca", is native to Brazil south region, used in folk medicine as anti-emetic and in the treatment of diabetes. This work reports the isolation and structural identification of a flavonoid glycoside, a triterpene, a coumarin and two benzoic acid derivatives, aiming at contributing to the chemotaxonomy of the genus Richardia, through a phytochemical study of Richardia brasiliensis. By means of this study the metabolites isorhamnetin-3-O-rutinoside, oleanolic acid, the coumarin scopoletin and $p$-hydroxy-benzoic and $m$-methoxy-p-hydroxybenzoic acids were isolated and identified. All of them, but the latter, were isolated for the first time in the genus, thereby presenting relevant chemotaxonomic importance to it. The structures were identified using spectroscopic techniques such as IR, one and two-dimensional ${ }^{1} \mathrm{H}$ and ${ }^{13} \mathrm{C}$ NMR besides comparison with literature data.
\end{abstract}

Keywords: Rubiaceae, Richardia brasiliensis, isorhamnetin-3-O-rutinoside, oleanolic acid, scopoletin.

\section{INTRODUCTION}

Since ancient times the world population has been using medicinal plants as raw material in the informal treatment, healing and prevention of their illnesses. That use dates the beginning of the civilization, when man took conscience of the need to fight against the diseases that afflicted the body and has arrived nowadays, being often the only effective therapeutic recourse available in many communities (Di Stasi, 1996).

Despite its distant history, a great part of the world flora is unknown because among the 250,000 to 500,000 plant species existing in nature not more than $10 \%$ were examined under chemical, biological and pharmacological aspects (Verpoorte, 1998). Brazil has a great diversity on plants that possess non-researched 
medicinal potential and are promising sources of therapeutic and pharmacological innovations to the most diverse areas of human health (Almeida et al., 2001; Souza et al., 2003; Rocha et al., 2005; Amaral et al., 2006; Barbosa-Filho et al., 2006; Barbosa-Filho et al., 2007; Oliveira et al., 2007; Barbosa-Filho et al., 2008).

Knowledge increasingly deepened on medicinal plants, developed through integrated studies in the fields of botany, chemistry, pharmacology, and other related sciences is vital to give support and greater longevity to the use of the floristic potential still existing on the planet.

Continuing the research on medicinal plants, the species Richardia brasiliensis Gomes ("poaia-branca") was taken as object of study. This species is used in folk medicine as anti-emetic and in the treatment of diabetes and belongs to the Rubiaceae family which is considered one of the biggest families among the Angiosperms, comprising around 637 genera and approximately 10,700 species, occurring essentially in tropical regions of Brazil and presenting great importance to food, ornamental and pharmaceutical industries (Mongrand et al., 2005; Adolpho et al., 2006; Coelho et al., 2006; Agra et al., 2007).

Rubiaceae species are known as bioproducers of alkaloids, tannins, saponins, steroids, terpenes and flavonoids, besides the report that some species are important to traditional medicine (Adolpho et al., 2006; Carbonezi et al., 2004; Hamerski et al., 2005; Silva et al., 2006; Alam et al., 2008; Cardoso et al., 2008).

Considering the wealth of metabolites of the family Rubiaceae, the phytochemical study of species that represent the genera of this family, especially of the genus Richardia whose chemistry is still little known (Tomaz et al., 2008), can lead to the discovery of new sources of naturally active substances. This work related to the phytochemical study of a specie of the genus Richardia shows the latter as a bioproducer of different classes of metabolites like terpenes and flavonoid glycoside.

The terpenoids comprise a great family of secondary metabolites that are known by their biological and physiological functions, and for this reason they are used in the pharmaceutical area. Maybe, triterpenes constitute the most important group of terpenoids. They present a lot of medicinal properties, specially the antiinflammatory, analgesic, cardiovascular and anti-tumor effects (Niero and Malheiros, 2007). On the other hand, the flavonoids are part of the group of phenolic compounds and are known to possess antioxidant, antiulcer, cardiovascular, among other activities.

The presence of these classes of compounds in the species Richardia brasiliensis shows the potential of this genus to be investigated through pharmacognostic studies.

\section{MATERIAL AND METHODS}

\section{Plant material}

The plant material of Richardia brasiliensis Gomes was collected in August 2006, in the city of Santa Rita, State of Paraíba, and was identified by Prof. Maria de Fátima Agra, from the Setor de Botânica of Laboratório de Tecnologia Farmacêutica "Prof. Delby Fernandes de Medeiros" (LTF/UFPB). A voucher specimen is deposited in the Herbário Prof. Lauro Pires Xavier (JPB), from Universidade Federal da Paraíba under the code Agra et al. 3195.

\section{Obtaining and partitioning of the extracts}

Dried and powdered plant material $(2.280 \mathrm{~kg})$ was subjected to exhaustive maceration with ethanol (EtOH) $95 \%$ in a stainless steel for three consecutive days. This process was repeated until the maximum extraction of the chemical constituents. The obtained ethanol solution was filtered and then concentrated in rotatory evaporator under average temperature of $50{ }^{\circ} \mathrm{C}$ yielding the crude ethanol extract (CEE) which weighed $177 \mathrm{~g}$ with an yield of $7.76 \% .2 \mathrm{~g}$ of this extract were separated to preliminary phytochemical evaluation, 25 $\mathrm{g}$ were reserved and the rest $(150 \mathrm{~g})$ was solubilized in a mixture of $\mathrm{MeOH}: \mathrm{H}_{2} \mathrm{O}(3: 7 \mathrm{v} / \mathrm{v})$ under mechanical agitation for 60 minutes, obtaining a hydroalcoholic solution I which was submitted to liquid/liquid partition in a separation funnel, under exhaustive manual agitation, using the solvents hexane, chloroform and ethyl acetate. The obtained solutions were treated with anhydrous sodium sulphate $\left(\mathrm{Na}_{2} \mathrm{SO}_{4}\right)$ and submitted to filtration under reduced pressure. After this process, the solvents were evaporated in rotatory evaporator under average temperature of $50{ }^{\circ} \mathrm{C}$, yielding the following fractions: hexane (23.3 g), chloroform (15 g) and ethyl acetate $(6.9 \mathrm{~g})$.

\section{Isolation of the chemical constituents}

The ethyl acetate fraction ( $2 \mathrm{~g}$ ) was subjected to chromatography on a column packed with Sephadex LH 20 and eluted with chloroform and methanol (50\% : $50 \%) .14$ fractions were obtained and joined according to their Rf's after being analysed through analytical thin-layer chromatography (TLC). The group of fractions 12-13 was chromatographed on column with Sephadex LH 20, eluted with chloroform and methanol $(50 \%: 50 \%)$ to give 9 sub-fractions that were joined according to their Rf's after analysis on analytical TLC. The fraction 12-13.(2) was subjected to preparative TLC using chloroform and ethyl acetate (83\%:17\%) as eluents, obtaing 3 sub-fractions. The sub-fraction 1213.(2).(1) was subjected to successive chromatographic purification, resulting on a yellow solid that was coded 


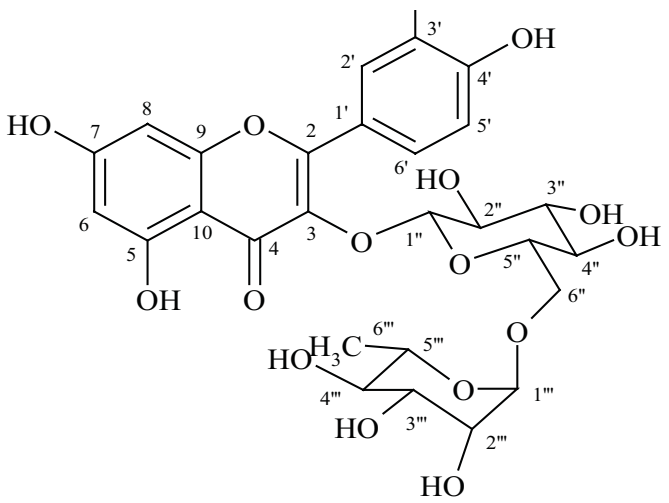

Isorhamnetin-3-O-rutinoside<smiles>C=C(O)c1ccc(O)c(OC)c1</smiles>

$m$-Methoxy-p-hydroxy-benzoic acid<smiles>COc1cc2ccc(=O)oc2cc1O</smiles>

Figure 1. Metabolites isolated from Richardia brasiliensis Gomes.

as substance $1(26 \mathrm{mg})$ and submitted to spectral analysis.

The fraction 14-16 was purified through preparative TLC, using chloroform and ethyl acetate $(50 \%: 50 \%)$ as eluents, showing itself as amorphous solid which resulted in the substance $2(19 \mathrm{mg})$, that was subjected to spectral analysis.

An aliquot of $10 \mathrm{~g}$ of the chloroform fraction was subjected to CC, using $200 \mathrm{~g}$ of silica gel 60 (Art. 7734 MERCK) and eluting with hexane, chloroform and methanol pure or in binary mixtures, in increasing degree of polarity yielding more than 400 fractions of $100 \mathrm{~mL}$ that were concentrated in rotatory evaporator and joined by analytical TLC according to their Rfs.

The fractions 284-322, obtained from the column with pure chloroform or with chloroform and methanol in binary mixtures $(0.5 \%$ to $2 \%$ of methanol), were recrystallized with methanol giving a white precipitate, coded as substance $3(685 \mathrm{mg})$ which showed itself as a single spot through analytical TLC. It was subjected, then, to spectral analysis.

The fractions 196-210 were submitted to preparative TLC, using hexane and ethyl acetate $(70 \%: 30 \%)$ as eluents, yielding 5 sub-fractions coded as: (196-210) 1; (196-210) 2;

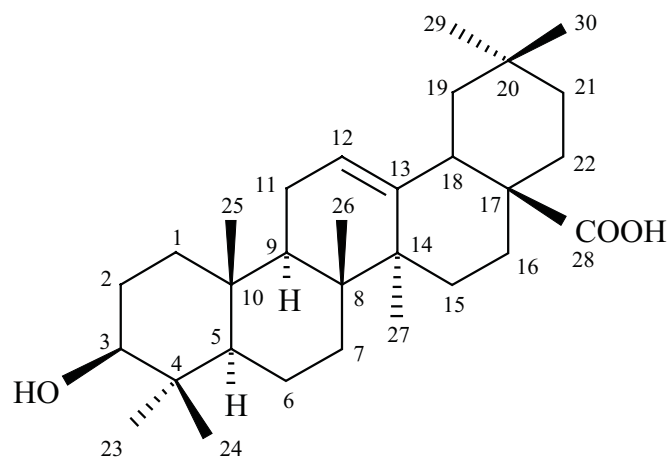

Oleanolic acid<smiles>O=C(O)c1ccc(O)cc1</smiles>

(196-210) 3; (196-210) 4; (196-210) 5. The sub-fraction (196210) 5 , after preparative TLC, using hexane and ethyl acetate ( $75 \%: 25 \%)$ as eluents, resulted in crystals and showed itself as a single spot through analytical TLC, being coded as substance $4(67 \mathrm{mg})$ and subjected to spectral analysis.

\section{RESULTS AND DISCUSSION}

\section{Structure determination of 1}

The substance coded as 1 showed itself as a yellow solid, soluble in methanol, with yield of $0.0011 \%$.

The spectrum of 1 in the region of IR revealed the presence of a strong absorption band in $3404 \mathrm{~cm}^{-}$ ${ }^{1}$, suggesting the presence of hydroxyl groups in the molecule. Absorptions between 1601 and $1429 \mathrm{~cm}^{-1}$ were verified and attributed to $\mathrm{C}=\mathrm{C}$ of aromatic ring. It can be observed a signal characteristic of chelated ketone carbonyl in $1655 \mathrm{~cm}^{-1}$, being possible to infer the presence of this functional group in the structure of the substance in question.

The ${ }^{13} \mathrm{C}$ NMR spectrum (125 MHz, CD 3 OD) utilizing the techniques Broad Brand and DEPT-135 revealed the presence of 28 spectral lines. According to the observed chemical shifts, it was possible to infer that among the twenty-eight carbon atoms, two are referable to methyl carbons $\left(\delta_{\mathrm{C}} 57.10\right.$ and $\left.\delta_{\mathrm{C}} 18.11\right)$; one is referable to methylene carbon $\left(\delta_{C} 67.56\right)$; five are referable to aromatic methyne carbons $\left(\delta_{C} 100.20 ; 95.07\right.$; $114.78 ; 116.13 ; 123.91)$; ten to aliphatic oxymethyne carbons $\left(\delta_{\mathrm{C}} 105.12 ; 73.24 ; 75.66 ; 72.43 ; 75.16 ; 102.08\right.$; $70.18 ; 72.22 ; 73.98 ; 69.86)$ and the other ten signals 
refer to non-hydrogen carbons $\left(\delta_{\mathrm{C}} 158.99 ; 135.63\right.$; $179.60 ; 163.15 ; 166.51 ; 158.66 ; 105.75 ; 123.12 ; 148.55$; 151.03).

The signal in $\delta_{\mathrm{C}} 179.60$ was suggested to be absorption of a flavone carbonyl, corroborating the IR spectrum which showed an absorption band to chelated carbonyl $\left(155.4 \mathrm{~cm}^{-1}\right)$. The signals in $\delta_{\mathrm{C}} 158.66$ and $\delta_{\mathrm{C}}$ 135.63 were attributed, after comparison with literature (Pizzolatti et al., 2003; Rastrelli et al., 1995), to the carbons $\mathrm{C}-2$ and $\mathrm{C}-3$ respectively, fact that strengthened the suggestion of 1 being a flavone.

The ${ }^{1} \mathrm{H}$ NMR spectrum (500 $\left.\mathrm{MHz}, \mathrm{CD}_{3} \mathrm{OD}\right)$ showed signals in $\delta_{\mathrm{H}} 8.03(\mathrm{~d}, J=2 \mathrm{~Hz}), \delta_{\mathrm{H}} 7.60(\mathrm{dd}, J=2$ $\mathrm{Hz}$ and $8.5 \mathrm{~Hz})$ and $\delta_{\mathrm{H}} 6.91(\mathrm{~d}, J=8.5 \mathrm{~Hz})$ that were attributed, respectively, to the hydrogens H-2, H-6 and $\mathrm{H}-5$ '. Thus, the presence of a trisubstituted flavonoid Bring could be inferred, characterizing an $\mathrm{ABX}$ system with substituents in 3 'and 4' in 1 . The presence of a methoxyl was evidenced by a characteristic signal in $\delta_{\mathrm{H}}$ $3.97(\mathrm{~s}, 3 \mathrm{H})$ and corroborated by the ${ }^{13} \mathrm{C}$ NMR spectrum which presented a signal in $\delta_{\mathrm{C}} 57.10$ that is characteristic of sterically unimpeded methoxyl of aromatic ring.

The ${ }^{1} \mathrm{H}$ NMR spectrum showed two doublets in $\delta_{\mathrm{H}} 6.21(1 \mathrm{H}, \mathrm{d}, J=2 \mathrm{~Hz})$ and $\delta_{\mathrm{H}} 6.41(1 \mathrm{H}, \mathrm{d}, J=2 \mathrm{~Hz})$ that are referable, respectively, to $\mathrm{H}-6$ and $\mathrm{H}-8$ of a flavonoid A-ring.

The diglucoside nature of the substance was evidenced by the number of oxymethyne signals observed in the ${ }^{1} \mathrm{H}$ and ${ }^{13} \mathrm{C}$ NMR spectra. The two glycoside units were identified as glucose and rhamnose based on ${ }^{1} \mathrm{H}$ and ${ }^{13} \mathrm{C}$ NMR spectral data. The doublets in $\delta_{\mathrm{H}} 5.23(\mathrm{~d}, J=7.8 \mathrm{~Hz})$ and $\delta_{\mathrm{H}} 4.54(\mathrm{~d}, J=1.1 \mathrm{~Hz})$ suggested themselves to be two anomeric hydrogens of the glucose and rhamnose molecules, respectively. This suggestion was strengthened by the ${ }^{13} \mathrm{C}$ RMN spectrum which showed absorptions in $\delta_{C} 105.12$ attributed to the anomeric carbon of the glucose unit and in $\delta_{\mathrm{C}} 18.11$ and $\delta_{\mathrm{C}} 102.08$, that are referable to the methyl and to the anomeric carbon of the rhamnose unit, respectively.

The characterization and the location of the diglucoside unit (rutinoside) in C-3 was based on the following observations: a) the chemical shift of C-2 $\left(\delta_{C}\right.$ 158.99), revealed by the ${ }^{13} \mathrm{C}$ NMR spectrum, suggested the presence of glycoside in $\mathrm{C}-3$; b) the long-distance correlation between the glucose anomeric hydrogen $\mathrm{H}-$ 1 " $\left(\delta_{\mathrm{H}} 5.23, \mathrm{~d}, J=7.8 \mathrm{~Hz}\right)$ and the carbon $\mathrm{C}-3\left(\delta_{\mathrm{C}} 133.53\right.$; $\left.{ }^{3} \mathrm{~J}_{\mathrm{CH}}\right)$, observed in the HMBC spectrum, permitted to define the bond $-O$ rutinoside; $\mathrm{c})$ the chemical shift of the glucose methylene carbon $\left(\delta_{\mathrm{C}} 67.56\right)$ permitted the location of the rhamnose unit in this carbon atom, since the signal of hydroxymethylene group free of a glycoside unit appears around $\delta_{\mathrm{C}} 62.12$ (Pizzolatti et al., $2003)$; d) the HMBC spectrum revealed the correlation between the rhamnose anomeric hydrogen $\mathrm{H}-1$ "' $\left(\delta_{\mathrm{H}}\right.$ $4.54, \mathrm{~d}, J=1.1$ ) and the glucose methylene carbon C- 6 ".

Through the two-bond correlations $\left({ }^{2} J_{\mathrm{CH}}\right)$ of H-6 $\left(\delta_{\mathrm{H}} 6.21\right)$ with C-7 $\left(\delta_{\mathrm{C}} 166.51\right)$ and H-6 $\left(\delta_{\mathrm{H}} 6.21\right)$ with $\mathrm{C}-5\left(\delta_{\mathrm{C}} 163.15\right)$ it was possible to determine that C-5 and C-7 sustain hydroxyl. Literature data for C-3' and C-4' (Rastrelli et al., 1995) were suggested to be inverted. The three-bond correlation $\left({ }^{3} \mathrm{~J}_{\mathrm{CH}}\right)$ between H-6' $\left(\delta_{\mathrm{H}} 7.60\right)$ and C-4' $\left(\delta_{\mathrm{C}} 151.03\right)$ and the ${ }^{2} \mathrm{~J}_{\mathrm{CH}}$ of $\mathrm{H}-2$ ' $\left(\delta_{\mathrm{H}} 8.03\right)$ with $\mathrm{C}-3^{\prime}\left(\delta_{\mathrm{C}} 148.55\right)$ unambiguously defined those values.

The observation of the homonuclear correlation spectrum NOESY showed the spatial coupling between the aromatic hydrogen $\mathrm{H}^{2} 2^{\prime}\left(\delta_{\mathrm{H}} 8.03\right)$ and the methoxyl hydrogens, thus suggesting that the methoxyl would be in the position C-3', corroborating the HMBC spectrum that presented three-bond correlation of the methoxyl hydrogens $\left(\delta_{\mathrm{H}} 3.97\right)$ with $\mathrm{C}-3^{\prime}\left(\delta_{\mathrm{C}} 148.55\right)$.

The analysis of the one and two-dimensional ${ }^{1} \mathrm{H}$ and ${ }^{13} \mathrm{C}$ NMR data of 1 and the comparison with values found in literature (Rastrelli, et al., 1995) permitted to identify the substance 1 as the glycoside flavonoid isorhamnetin-3-O-rutinoside, being the first report about it in the genus Richardia.

\section{Structure determination of 3}

The substance coded as 3 showed itself as a white powder, soluble in chloroform, with yield of $0.03 \%$.

The ${ }^{13} \mathrm{C}$ NMR spectrum (50 $\mathrm{MHz}, \mathrm{CD}_{3} \mathrm{OD}$ ) utilizing the APT technique revealed the presence of thirty signals, referable to one carbonyl carbon $\left(\delta_{\mathrm{C}}\right.$ $183.2)$, seven non-hydrogen carbons $\left(\delta_{\mathrm{C}} 38.7 ; \delta_{\mathrm{C}} 39.2\right.$; $\left.\delta_{\mathrm{C}} 37.0 ; \delta_{\mathrm{C}} 143.5 ; \delta_{\mathrm{C}} 46.4 ; \delta_{\mathrm{C}} 30.6 ; \delta_{\mathrm{C}} 41.5\right)$, five methyne carbons $\left(\delta_{\mathrm{C}} 55.1 ; \delta_{\mathrm{C}} 47.5 ; \delta_{\mathrm{C}} 122.6 ; \delta_{\mathrm{C}} 79.0 ; \delta_{\mathrm{C}} 40.9\right)$, ten methylene carbons $\left(\delta_{\mathrm{C}} 38.3 ; \delta_{\mathrm{C}} 27.1 ; \delta_{\mathrm{C}} 18.2 ; \delta_{\mathrm{C}}\right.$ $\left.32.6 ; \delta_{\mathrm{C}} 22.9 ; \delta_{\mathrm{C}} 27.6 ; \delta_{\mathrm{C}} 23.3 ; \delta_{\mathrm{C}} 45.8 ; \delta_{\mathrm{C}} 33.7 ; \delta_{\mathrm{C}} 32.4\right)$ and seven methyl carbons $\left(\delta_{\mathrm{C}} 28.0 ; \delta_{\mathrm{C}} 15.5 ; \delta_{\mathrm{C}} 15.2 ; \delta_{\mathrm{C}}\right.$ $\left.17.5 ; \delta_{\mathrm{C}} 25.9 ; \delta_{\mathrm{C}} 33.0 ; \delta_{\mathrm{C}} 23.5\right)$, suggesting a pentacyclic triterpene skeleton to 3 .

The signals to non-hydrogen carbon in $\delta_{C}$ 143.5 and to methyne carbon in $\delta_{C} 122.6$ suggested the presence of a double bond in the molecule and the signal in $\delta_{\mathrm{C}} 79.0$ indicated the presence of oxymethyne carbon.

The ${ }^{1} \mathrm{H}$ NRM spectrum (200 $\mathrm{MHz}, \mathrm{CDCl}_{3}$ ) of 3 showed an envelope of simple signals in the region between 1.89 e $0.73 \mathrm{ppm}$, which are characteristic of methyl hydrogens of pentacyclic triterpenes. The presence of a large singlet in $\delta_{\mathrm{H}} 5.25(1 \mathrm{H})$ and a double doublet in $2.80(1 \mathrm{H})$ is compatible with the hydrogens 12 and 18 of the ${ }^{12} \Delta$ oleanane skeleton.

The analysis of the ${ }^{1} \mathrm{H} \mathrm{e}{ }^{13} \mathrm{C}$ NMR spectral data of 3 and its comparison with models from literature (Mahato and Kundu, 1994; Pauletti et al., 2006) permitted to identify the substance 3 as the $3 \beta$-hydroxyolean-12en-28-oic, known as oleanolic acid, reported for the first time in the genus Richardia. 


\section{Other constituents}

By means of analysis of the spectral data of one and two-dimensional $\mathrm{NMR}{ }^{1} \mathrm{H}$ e ${ }^{13} \mathrm{C}$ and its comparison with literature data the coumarin 7-hydroxy-6methoxy-2H-1-benzopyran-2-one, known as scopoletin (substance 4) (Vasconcelos et al., 1998; Carvalho et al., 2006; Razavi et al., 2008) and the mixture of the $m$ methoxy- $p$-hydroxy-benzoic and $p$-hydroxy-benzoic acids (substance 2) (Silva, 2002; Silveira and Pessoa, 2005) were also identified.

\section{ACKNOWLEDGMENTS}

The authors are grateful to CNPq, CAPES, IMSEAR and RENORBIO for financial support and CENAUREM for accomplishing the spectra of isorhamnetin-3- $O$-rutinoside, $m$-methoxy- $p$-hydroxybenzoic and $p$-hydroxy-benzoic acids.

\section{REFERENCES}

Agra MF, França PF, Barbosa-Filho JM 2007. Synopsis of the plants known as medicinal and poisonous in Northeast of Brazil. Rev Bras Farmacogn 17: 114140.

Adolpho LO, Dalcol I, Silva VS, Stücker C 2006. Atividade antimicrobiana e antioxidante das frações de Richardia brasiliensis Gomes (Rubiaceae). XIV Jornada de Jovens Pesquisadores do AUGM.

Alam MA, Akter R, Subhan N, zur Rahman MM, Majumder MM, Nahar L, Sarker SD 2008. Antidiarrhoeal property of the hydroethanolic extract of the flowering tops of Anthocephalus cadamba. Rev Bras Farmacogn 18: 155-159.

Almeida RN, Navarro DS, Barbosa-Filho JM 2001. Plants with central analgesic activity. Phytomedicine 8 : 310-322.

Amaral FMM, Ribeiro MNS, Barbosa-Filho JM, Reis AS, Nascimento FRF, Macedo RO 2006. Plants and chemical constituents with giardicidal activity. Rev Bras Farmacogn 16 (Supl.): 696-720.

Barbosa-Filho JM, Medeiros KCP, Diniz MFFM, Batista LM, Athayde-Filho PF, Silva MS, Cunha EVL, Almeida JRGS, Quintans-Júnior LJ 2006. Natural products inhibitors of the enzyme acetylcholinesterase. Rev Bras Farmacogn 16: 258-285.

Barbosa-Filho JM, Nascimento-Júnior FA, Tomaz ACA, Athayde-Filho PF, Silva MS, Cunha EVL, Souza MFV, Batista LM, Diniz MFFM 2007. Natural products with antileprotic activity. Rev Bras Farmacogn 17: 141-148.

Barbosa-Filho JM, Alencar AA, Nunes XP, Tomaz ACA, Sena-Filho JG, Athayde-Filho PF, Silva MS, Souza MFV, da-Cunha EVL 2008. Sources of alpha-, beta, gamma-, delta- and epsilon-carotenes: A twentieth century review. Rev Bras Farmacogn 18: 135-154.

Carbonezi CA, Hamerski L, Flausino Júnior AO, Furlan M, Bolzani VS, Young, MCM 2004. Determinação por RMN das configurações relativas e conformações de alcalóides oxindólicos isolados de Uncaria guianensis. Quim Nova 27: 878-881.

Cardoso CL, Silva DHS, Young MCM, Castro-Gamboa I, Bolzani VS 2008. Indole monoterpene alkaloids from Chimarrhis turbinata DC Prodr.: a contribution to the chemotaxonomic studies of the Rubiaceae family. Rev Bras Farmacogn 18: 26-29.

Carvalho MG, Alves CCF, Werle AA, Braz-Filho R 2006. Metabólitos especiais isolados de Laseguea erecta (Apocynaceae). Rev Bras Farmacogn 16: 497-500.

Coelho VPM, Agra MF, Barbosa MRV 2006. Estudo farmacobotânico das folhas de Tocoyena formosa (Cham.\& Schltdl) K. Schum. (Rubiaceae). Rev Bras Farmacogn 16: 170-177.

Di Stasi LC 1996. Plantas medicinais: arte e ciência. Um guia de estudo interdisciplinar. São Paulo, Editora UNESP.

Hamerski L, Cavalheiro AJ, Carbonezi CA, Young MCM, Bolzani VS 2005. Saponinas triterpênicas de Tocoyena brasiliensis Mart. (Rubiaceae). Quim Nova 28: 601-604.

Mahato SB, Kundu AP 1994. ${ }^{13}$ C NMR Spectra of pentacyclic triterpenoids - A compilation and some salient features. Phytochemistry 37: 1517-1575.

Mongrand S, Badoc A, Patouille B, Lacomblez C, Chavent M, Bessoule J 2005. Chemotaxonimy of the Rubiaceae family based on leaf fatty acid composition. Phytochemistry 66: 549-559.

Niero R, Malheiros A 2007. Triterpenos e sua importância químico-medicinal. In Yunes RA, Cechinel Filho V 2007. Química de produtos naturais, novos fármacos e a moderna farmacognosia. Itajaí, $1^{\text {a }}$ Ed, Editora UNIVALI, $\mathrm{p}$ 237-258.

Oliveira FQ, Gobira B, Guimarães C, Batista J, Barreto M, Souza M 2007. Espécies vegetais indicadas na odontologia. Rev Bras Farmacogn 17: 466-476.

Pauletti PM, Teles HL, Silva DHS, Araújo AR, Bolzani VS 2006. The Styracaceae. Rev Bras Farmacogn 16: 576-590.

Pizzolatti MG, Cunha Júnior A, Szpoganicz B, Sousa E, Braz-Filho R, Schripsema J 2003. Flavonóides glicosilados das folhas e flores de Bauhinia forficata (Leguminosae). Quim Nova 26: 466-469.

Rastrelli L, Saturnino P, Schettino O, Dini A 1995. Studies on the constituents of Chenopodium pallidicaule (Cañihua) seeds. Isolation and characterization of two new flavonol glicosides. J Agric Food Chem 43: 2020-2024.

Razavi SM, Nazemiyeh H, Hajiboland R, Kumarasamy Y, Delazar A, Nahar L, Sarker SD 2008. Coumarins from the aerial parts of Prangos uloptera (Apiaceae). Rev Bras Farmacogn 18: 1-5.

Rocha LG, Almeida JRGS, Macedo RO, Barbosa-Filho JM 2005. A review of natural products with antileishmanial activity. Phytomedicine 12: 514535.

Silva TMS 2002. Estudo Químico de Espécies de Solanum. Tese (Doutorado em Química Orgânica), Universidade Federal Rural do Rio de Janeiro, Rio de Janeiro-RJ.

Silva VC, Silva GH, Bolzani VS, Lopes MN 2006. Isolation of lignans glycosides from Alibertia sessilis (Vell.) K. Schum. (Rubiaceae) by preparative high-performance liquid chromatography. Eclet Quim 31: 55-58.

Silveira ER, Pessoa ODL 2005. Constituintes micromoleculares 
de plantas do Nordeste com potencial farmacológico. Fortaleza-CE, 1ª Ed., Editora Expressão Gráfica, p. 137-143.

Souza LA, Mourão KSM, Moscheta IS, Rosa SM 2003. Morfologia e anatomia da flor de Pilocarpus pennatifolius Lem. (Rutaceae). Rev Bras Bot 26: 175-184.

Tomaz ACA, Nogueira RBSS, Pinto DS, Agra MF, Souza MFV, da-Cunha EVL 2008. Chemical constiuents from Richardia grandiflora (Cham. \& Schltdl.) Steud. (Rubiaceae). Rev Bras Farmacogn 18: 47-52.

Vasconcelos JMF, Silva MAS, Cavaleiro JAS 1998. Chromones and flavanones from Artemisia campestris subsp. maritima. Phytochemistry 49: 1421-1424.

Verpoorte R 1998. Exploration of nature's chemodiversity: the role of secondary metabolites as leads in drugs development. Drug Discov Today 3: 232-238. 